\title{
UPAYA MENINGKATKAN HASIL BELAJAR DALAM PEMBELAJARAN DARING MATA PELAJARAN SOSIOLOGI MATERI PERMASALAHAN SOSIAL YANG DISEBABKAN OLEH PERUBAHAN SOSIAL DENGAN MODEL PROBLEM BASED LEARNING MELALUI APLIKASI LMS “SMABA-EL” DI KELAS XII IPS 1 SMA NEGERI 1 BANDONGAN TAHUN PELAJARAN 2020/2021
}

Oleh:

\author{
Feryda Indriyanti Putri ${ }^{1}$
}

\begin{abstract}
Abstrak
Penelitian ini bertujuan untuk mendeskripsikan peningkatan hasil belajar dalam pembelajaran daring dengan penerapan model Problem Based Learning melalui aplikasi LMS “SMABA-EL". Penelitian ini dilakukan dengan subjek penelitian peserta didik kelas XII IPS 1 di SMA Negeri 1 Bandongan Kabupaten Magelang semester I Tahun Pelajaran 2020/2021 sebanyak 26 peserta didik, terdiri dari 12 peserta didik laki-laki dan 14 peserta didik perempuan. Metode yang digunakan adalah Penelitian Tindakan Kelas (PTK) dengan desain penelitian menggunakan model Kemmis dan Mc. Taggart yang terdiri dari tahap perencanaan, tindakan, observasi, refleksi. Teknik pengumpulan data dengan menggunakan wawancara, tes, observasi, dokumen dan dokumentasi. Dari hasil penelitian pada pra siklus menggunakan tes kognitif, menunjukkan sebanyak 10 peserta didik $(38,46$ $\%$ ) yang hasil belajarnya mengalami ketuntasan dengan Kriteria Ketuntasan Minimal (KKM) 67 dan nilai rata-rata kelas sebesar 60,38. Kemudian meningkat pada siklus I sampai siklus II yaitu, siklus I sebesar $57,69 \%$ peserta didik yang mengalami ketuntasan dengan nilai rata-rata kelas sebesar 68,27 dan siklus II sebesar 80,77\% peserta didik yang mengalami ketuntasan dengan nilai rata-rata kelas sebesar 79,81. Kesimpulan dari penelitian ini adalah dengan penerapan model Problem Based Learning melalui aplikasi LMS "SMABA-EL" dapat meningkatkan hasil belajar dalam pembelajaran daring mata pelajaran Sosiologi materi permasalahan sosial yang disebabkan oleh perubahan sosial di kelas XII IPS 1 SMA Negeri 1 Bandongan Tahun Pelajaran 2020/2021.
\end{abstract}

Kata Kunci: Hasil Belajar, Problem Based Learning, LMS “SMABA-EL”

\footnotetext{
${ }^{1}$ Guru Sosiologi di SMA Negeri 1 Bandongan ferydaindriyantiputri@gmail.com
} 


\section{PENDAHULUAN}

Sejak merebaknya pandemi yang disebabkan oleh virus Corona di Indonesia, banyak cara yang dilakukan oleh pemerintah untuk mencegah penyebarannya. Salah satunya adalah melalui pembelajaran daring yang diatur melalui Surat Edaran Kemdikbud No 4 Tahun 2020 mengenai Pelaksanaan Pendidikan Dalam Masa Darurat Coronavirus Disease (Covid-19). Ada tiga poin kebijakan terkait pembelajaran daring, pertama, pembelajaran daring untuk memberi pengalaman belajar yang bermakna, tanpa terbebani tuntutan menuntaskan seluruh capaian kurikulum untuk kenaikan kelas maupun kelulusan. Kedua, dapat difokuskan pada pendidikan kecakapan hidup, antara lain mengenai pandemi Covid-19. Ketiga, aktivitas dan tugas pembelajaran dapat bervariasi antar peserta didik, sesuai minat dan kondisi masing-masing, termasuk mempertimbangkan kesenjangan akses atau fasilitas belajar di rumah.

Menurut Purwanto (2009), hasil belajar dapat dijelaskan dengan memahami dua kata yang membentuknya, yaitu hasil dan belajar. Pengertian hasil (produk) menunjuk pada suatu perolehan akibat dilakukannya suatu aktivitas atau proses yang mengakibatkan berubahnya input secara fungsional. Sedangkan pengertian belajar dalam arti luas adalah semua persentuhan pribadi dengan lingkungan yang menimbulkan perubahan perilaku.

Menurut Nana Sudjana (2017), hasil belajar adalah kemampuankemampuan yang dimiliki peserta didik setelah ia menerima pengalaman belajarnya. Sudjana membagi tiga klasifikasi hasil belajar, yaitu:

a. Kognitif: berkenaan dengan hasil belajar intelektual yang terdiri enam aspek, yakni pengetahuan atau ingatan, pemahaman, aplikasi, analisis sintesis dan evaluasi.

b. Afektif: berkenaan dengan sikap dan nilai yang terdiri dari lima aspek yaitu: penerimaan, jawaban atau reaksi, penilaian, organisasi dan internalisasi.

c. Psikomotorik: berkenaan dengan hasil belajar keterampilan dan kemampuan bertindak. Ada enam 
aspek psikomotorik, yakni gerakan refleksi, keterampilan gerakan dasar, kemampuan perseptual, keharmonisan atau ketepatan, gerakan keterampilan kompleks, dan gerakan ekspresif dan interpretatif.

Dari pernyataan tersebut dapat dimengerti bahwa hasil belajar adalah kemampuan yang dimiliki peserta didik setelah menerima pengalaman belajar yang tampak pada perubahan tingkah laku atau kemampuankemampuan baik kemampuan peserta didik dari segi kognitif, afektif maupun psikomotor yang terjadi pada diri peserta didik setelah menerima pengalaman belajarnya, dimana perubahan tersebut dapat diamati dan diukur dalam bentuk pola-pola perbuatan, nilai-nilai, pengertianpengertian, sikap-sikap, apersepsi dan keterampilan.

Sehubungan dengan yang disebutkan di atas maka sosiologi harus dipelajari atau diperoleh melalui proses belajar yang berlangsung secara kondusif dalam pembelajaran daring sehingga peserta didik mampu mengembangkan kemampuan berpikir kritis dalam melihat fenomena sosial yang terjadi pada kehidupan sehari-hari berdasarkan sudut pandang sosiologi. Untuk mengetahui apakah peserta didik tersebut telah menguasai materi pembelajaran yang telah diajarkan melalui pembelajaran daring adalah dengan meningkatnya hasil belajar peserta didik.

Berdasarkan hasil observasi yang dilakukan peneliti dari bulan MaretSeptember 2020 di SMA Negeri 1 Bandongan, permasalahan yang didapat selama pembelajaran daring antara lain: 1) Motivasi peserta didik untuk mengikuti kegiatan pembelajaran daring rendah; 2) Keaktifan peserta didik dalam kegiatan pembelajaran daring rendah; 3) Kemampuan peserta didik untuk berpikir kritis masih rendah; 4) Peserta didik masih mengalami kesulitan dalam menghubungkan dan mengaplikasikan ilmu Sosiologi dalam kehidupan sehari-hari; 5) Hasil belajar Sosiologi peserta didik pada kegiatan pembelajaran daring masih rendah.

Hal ini dapat dilihat dari nilai Penilaian Harian KD 3.1 di kelas XII 
IPS 1, bahwa hasil belajar peserta didik pada mata pelajaran Sosiologi adalah $10(38,46 \%)$ dari 26 peserta didik yang sudah mencapai KKM, sedangkan $16(61,54 \%)$ peserta didik belum mencapai KKM dengan nilai rata-rata kelas sebesar 60,38. Rendahnya hasil belajar peserta didik berdasarkan hasil wawancara dengan peserta didik dikarenakan peserta didik masih belum bisa memahami materi yang disampaikan dan guru masih menggunakan metode ceramah dalam proses pembelajaran daring.

Melalui penerapan model pembelajaran Problem Based Learning diharapkan dapat meningkatkan hasil belajar peserta didik dalam pembelajaran daring sehingga fokus bahasan riset dalam penelitian ini adalah untuk mengetahui apakah dengan penerapan model Problem Based Learning melalui aplikasi LMS "SMABA-EL" dalam pembelajaran daring mata pelajaran Sosiologi materi permasalahan sosial yang disebabkan oleh perubahan sosial dapat meningkatkan hasil belajar peserta didik di kelas XII IPS 1 SMA Negeri 1 Bandongan.

\section{METODE PENELITIAN}

Penelitian ini merupakan jenis Penelitian Tindakan Kelas dengan pemaparan data secara deskriptif kualitatif dan data kuantitatif. Data kualitatif diperoleh dari lembar observasi dari setiap pelaksanaan tindakan (proses pembelajaran) dan data kuantitatif diperoleh dari tes akhir setiap siklus (hasil pembelajaran). Desain Penelitian Tindakan Kelas menggunakan model Kemmis dan Mc. Taggart. Mekanisme pelaksanaan penelitian direncanakan dalam bentuk 2 siklus yang tiap siklus terdapat empat tahapan, yaitu (1) tahap perencanaan, (2) tahap tindakan, (3) tahap observasi dan (4) refleksi. Penelitian dilaksanakan di SMA Negeri 1 Bandongan tahun pelajaran 2020/2021 semester gasal dengan subjek dalam penelitian ini adalah peserta didik kelas XII IPS 1 sebanyak 26 peserta didik, terdiri dari 12 peserta didik laki-laki dan 14 peserta didik perempuan yang berlangsung selama 1 bulan. Dikarenakan kondisi dan situasi yang tidak memungkinkan pertemuan secara langsung karena pandemi Covid-19, maka penelitian ini 
dilaksanakan pada pembelajaran Sosiologi dalam jaringan (daring) yang menggunakan LMS "SMABA-EL" sebagai pengganti kelasnya.

Data penelitian ini berupa data kualitatif dan kuantitatif yang diperoleh secara tes dan non tes. Teknik tes meliputi tes tulis dan menghasilkan data kuantitatif, sedangkan teknik non tes melalui kegiatan observasi baik itu ketika diskusi maupun presentasi.

Kriteria penilaian dalam penentuan keberhasilan peserta didik harus sesuai dengan standar nilai yang ditentukan pihak kurikulum SMA Negeri 1 Bandongan, yakni minimal nilai 67 untuk memenuhi Kriteria Ketuntasan Minimal (KKM). Dalam penelitian ini indikator keberhasilan meliputi ratarata hasil belajar peserta didik dalam satu kelas, rata-rata hasil belajar yang dimaksud adalah aspek kognitif. Adapun indikator capaian penilaian dalam penelitian ini adalah sebagai berikut.
Tabel 3.2 Capaian Nilai yang Ditargetkan

\begin{tabular}{|c|c|c|c|}
\hline \multirow{2}{*}{$\begin{array}{c}\text { Aspek Yang } \\
\text { Diukur }\end{array}$} & \multicolumn{2}{|c|}{$\begin{array}{c}\text { Capaian Nilai } \\
\text { Ditargetkan }\end{array}$} & \multirow{2}{*}{$\begin{array}{c}\text { Cara } \\
\text { Mengukur }\end{array}$} \\
\cline { 2 - 3 } & $\begin{array}{c}\text { Siklus } \\
\text { I }\end{array}$ & $\begin{array}{c}\text { Siklus } \\
\text { II }\end{array}$ & \\
\hline $\begin{array}{c}\text { Kognitif } \\
\text { (Ketuntasan } \\
\text { hasil belajar } \\
\text { peserta didik) }\end{array}$ & 56 & 74 & dari tes \\
Kognitif (Rata- \\
rata nilai kelas)
\end{tabular}

(Sumber: Peneliti, 2020: 43)

Cara menghitung persentase

ketuntasan KKM Siklus I dan II

Persentase $(\%) \equiv \mathrm{n}$
$\mathrm{N}$

Keterangan:

$\mathrm{n}$ : Jumlah peserta didik yang

tuntas/tidak tuntas

$\mathrm{N}$ : Jumlah peserta didik keseluruhan

Teknik analisis data yang digunakan dalam penelitian ini adalah analisis secara kuantitatif dan kualitatif. Teknik analisis kuantitatif untuk membandingkan peningkatan hasil belajar peserta didik. Sedangkan kualitatif dilakukan dengan cara membandingkan proses belajar yang dilakukan guru dan peserta didik saat menggunakan model Problem Based Learning pada setiap siklusnya. 
Dalam penelitian ini, peneliti menggunakan validitas isi untuk memperkuat data. Menurut Azwar (2012), validitas isi merupakan validasi yang dilakukan melalui pengujian terhadap kelayakan atau relevansi isi tes kepada yang berkompeten atau expert judgment. Validitas isi ini bersifat subjektif dari expert yang menilai, oleh karena itu, sejauhmana kesepakatan penilaian dari pada expert dapat mendukung tujuan pengukuran pada instrumen yang berfungsi secara valid. Berkaitan dengan penelitian validitas isi, bahan yang diuji atau dites relevan dengan kemampuan, pengetahuan, pelajaran, pengalaman dan latar belakang orang yang diuji. Berdasarkan penjelasan tersebut, maka dalam penelitian ini semua pertanyaan yang dibuat oleh peneliti sebagai tes hasil belajar siklus I dan siklus II diuji dengan validitas isi. Pertanyaan-pertanyaan tersebut di tes sesuai atau tidak dengan kemampuan, pengetahuan, pelajaran, pengalaman dan latar belakang peserta didik kelas XII IPS 1 SMA Negeri 1 Bandongan.
3. HASIL

Pelaksanaan siklus I selama 2 kali pertemuan yang dilaksanakan pada hari Senin, 19 Oktober 2020 dan Kamis, 22 Oktober 2020. Pelaksanaan tindakan siklus I terdiri dari empat tahapan yaitu perencanaan, tindakan, observasi dan refleksi.

\section{Gambar 4.1}

\section{Diagram Hasil Belajar Pra Siklus}

\section{Hasil Belajar Pra Siklus}

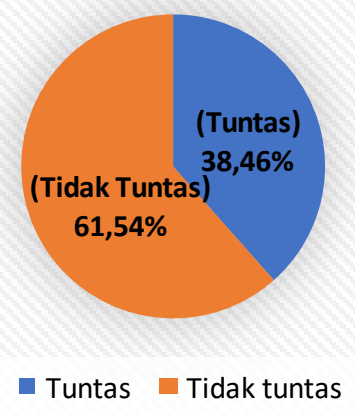

(Sumber: Peneliti, 2020: 48)

Dari gambar di atas diperoleh bahwa hasil belajar peserta didik masih rendah, peserta didik yang telah memenuhi Kriteria Ketuntasan Minimal (KKM) sebanyak 10 peserta didik dari 26 peserta didik, bila diprosentasekan sebesar $38,46 \%$. Peserta didik yang tidak memenuhi batas KKM yaitu sebesar $61,54 \%$. Rata-rata kelas yang diperoleh peserta 
didik pada penilaian kompetensi pengetahuan melalui pengerjaan tes evaluasi sebesar 60,38.

Setelah dilakukan tindakan pada siklus I dengan penerapan model Problem Based Learning melalui aplikasi LMS "SMABA-EL" dapat dilihat hasil ketuntasan belajar peserta didik pada tabel berikut.

Tabel 4.1

Hasil Ketuntasan Peserta Didik Siklus I Materi Permasalahan Sosial yang Disebabkan Perubahan Sosial

\begin{tabular}{|c|c|c|c|}
\hline No & Kriteria & $\begin{array}{c}\text { Jumlah } \\
\text { Peserta } \\
\text { Didik }\end{array}$ & Prosentase \\
\hline 1. & $\begin{array}{l}\text { Tuntas 67- } \\
100\end{array}$ & 15 & $57,69 \%$ \\
\hline 2. & Tidak & 11 & $42,31 \%$ \\
\hline \multicolumn{2}{|c|}{ Tuntas $<67$} & $\mathbf{2 6}$ & $\mathbf{1 0 0 , 0 0 \%}$ \\
\hline
\end{tabular}

(Sumber: Peneliti, 2020: 67)

Ketercapaian rata-rata hasil belajar kognitif peserta didik dalam satu kelas dapat dilihat pada tabel berikut.

Tabel 4.2

Tabel Ketercapaian Keberhasilan Siklus 1

\begin{tabular}{|c|c|c|l|}
\hline \multirow{2}{*}{$\begin{array}{c}\text { Dspek yang } \\
\text { Dinilai }\end{array}$} & \multicolumn{2}{|c|}{ Siklus I } & \multirow{2}{*}{ Keterangan } \\
\cline { 2 - 3 } & Target & Capaian & \\
\hline Ketuntasan & 56 & 57,69 & Meningkat \\
hasil belajar & & & \\
\hline
\end{tabular}

\begin{tabular}{|l|l|l|l|}
\hline peserta didik & & & \\
\hline Rata-rata & 67 & 68,27 & Meningkat \\
hasil belajar & & & \\
kognitif & & & \\
\hline
\end{tabular}

(Sumber: Peneliti, 2020: 68)

Berdasarkan analisis tes kognitif pada siklus I, diketahui bahwa jumlah peserta didik yang mencapai KKM sebanyak 15 dari 26 peserta didik kelas XII IPS 1 SMA Negeri 1 Bandongan. Kriteria Ketuntasan Minimal (KKM) untuk mata pelajaran sosiologi adalah 67 untuk SMA Negeri 1 Bandongan. Nilai rata-rata ini sudah mencapai target 67 dari nilai rata-rata kelas yaitu $68,27$.

Pencapaian pada penelitian ini dapat dilihat dari perbandingan hasil belajar yang diperoleh peserta didik antara pra siklus dengan siklus I. Adapun perbandingan hasil belajar peserta didik dapat dilihat pada diagram perbandingan pada gambar 4.2 sebagai berikut. 
Gambar 4.2

Diagram Perbandingan Hasil Belajar Pra Siklus dan Siklus I

\section{PERBANDINGAN HASIL BELAJAR PRA SIKLUS DAN SIKLUS I \\ E Tuntas E Tidak Tuntas}

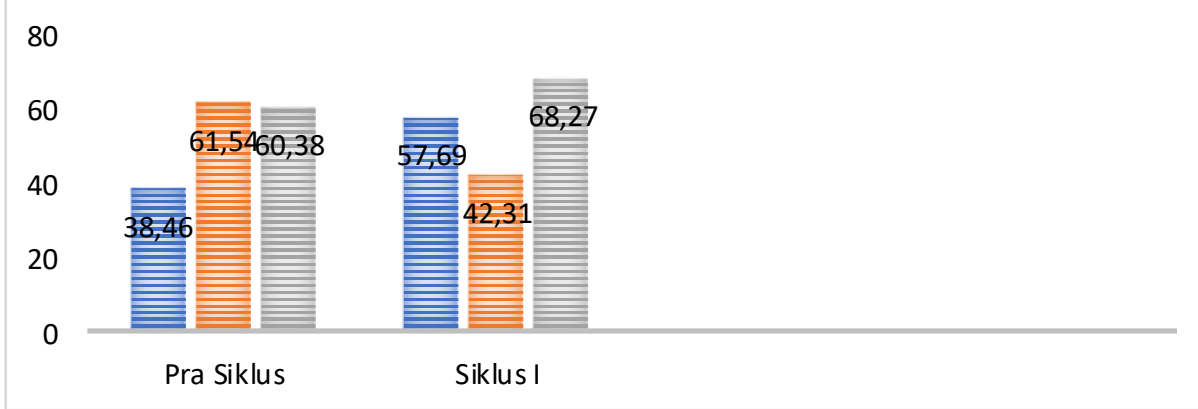

(Sumber: Peneliti, 2020: 68)

Berdasarkan data di atas menunjukkan peningkatan dari pra siklus ke siklus I untuk ketuntasan belajar sebesar $19,23 \%$ dan untuk rata-rata kelas mengalami peningkatan 7,89\%. Peningkatan peserta didik dalam hasil belajar setelah dilakukan tindakan siklus I sebanyak 5 peserta didik yang mengalami peningkatan dari hasil pra siklus. Meskipun mengalami peningkatan pada siklus I dan sudah mencapai indikator keberhasilan yang ditentukan tetapi hasil yang diperoleh belum maksimal, oleh karena itu perlu diadakan perbaikan pada siklus selanjutnya untuk hasil yang lebih maksimal.

Tindakan pada siklus II dengan penerapan model Problem Based Learning melalui aplikasi LMS "SMABA-EL" agak berbeda dengan siklus I. Perbedaannya adalah jika di siklus I penerapan model Problem Based Learning dalam kegiatan diskusi dilakukan dalam satu kelas, di siklus II kegiatan diskusi dilakukan secara berkelompok. Selain itu di siklus II juga dilakukan ice breaking untuk memulihkan semangat belajar peserta didik yang dilakukan diantara kegiatan diskusi dan presentasi. Hasil dari tindakan siklus II dapat dilihat 
dari hasil ketuntasan belajar peserta didik pada tabel berikut.

Tabel 4.3

Hasil Ketuntasan Peserta Didik Siklus II Materi Permasalahan Sosial yang Disebabkan Perubahan Sosial

\begin{tabular}{|c|l|c|c|}
\hline No. & Kriteria & $\begin{array}{c}\text { Jumlah } \\
\text { Peserta } \\
\text { Didik }\end{array}$ & $\begin{array}{c}\text { Prosen } \\
\text { tase }\end{array}$ \\
\hline 1. & $\begin{array}{l}\text { Tuntas 67- } \\
100\end{array}$ & 21 & 80,77 \\
$\%$ \\
\hline 2. & $\begin{array}{l}\text { Tidak Tuntas } \\
<67\end{array}$ & 5 & 19,23 \\
$\%$
\end{tabular}

(Sumber: Peneliti, 2020: 90)

Tabel 4.4

Tabel Ketercapaian Keberhasilan Siklus II

\begin{tabular}{|l|c|c|c|}
\hline \multicolumn{1}{|c|}{$\begin{array}{l}\text { Aspek yang } \\
\text { Dinilai }\end{array}$} & \multicolumn{2}{|c|}{ Siklus II } & Keterangan \\
\cline { 2 - 3 } & Target & Capaian & \\
\hline $\begin{array}{l}\text { Ketuntasan } \\
\text { hasil belajar } \\
\text { peserta }\end{array}$ & 74 & 80,77 & Meningkat \\
didik & & & \\
\hline $\begin{array}{l}\text { Rata-rata } \\
\text { hasil belajar }\end{array}$ & 74 & 79,81 & Meningkat \\
kognitif & & & \\
\hline
\end{tabular}

(Sumber: Peneliti, 2020: 92)

Berdasarkan analisis tes pengetahuan pada siklus II, diketahui bahwa jumlah peserta didik yang mencapai KKM sebanyak 21 dari 26 peserta didik kelas XII IPS 1 SMA Negeri 1 Bandongan. Kriteria Ketuntasan Minimal (KKM) untuk mata pelajaran sosiologi adalah 67 untuk SMA Negeri 1 Bandongan.
Nilai rata-rata ini sudah mencapai target 74 dari nilai rata-rata kelas yaitu 79,81 .

Pencapaian pada penelitian ini dapat dilihat dari perbandingan hasil belajar yang diperoleh peserta didik antara pra siklus, siklus I dengan siklus II. Adapun perbandingan hasil belajar peserta didik dapat dilihat pada tabel 4.5, tabel 4.6 dan gambar 4.3.

Tabel 4.5

Perbandingan Capaian Hasil Belajar Antarsiklus

\begin{tabular}{|c|c|c|c|c|c|c|}
\hline \multirow{2}{*}{$\begin{array}{c}\text { Krite } \\
\text { ria }\end{array}$} & \multicolumn{2}{|c|}{ Pra Siklus } & \multicolumn{2}{c|}{ Siklus I } & \multicolumn{2}{c|}{ Siklus II } \\
\cline { 2 - 7 } & Pes & Prose & Pes & Prose & Pes & Prose \\
& a & & $\begin{array}{c}\text { Did } \\
\text { erta }\end{array}$ & ntase & $\begin{array}{c}\text { erta } \\
\text { Did }\end{array}$ & \\
& Di & & ik & & ik & \\
dik & & & 15 & 57,69 & 21 & 80,77 \\
sunta & 10 & 38,46 & & $\%$ & & $\%$ \\
\hline $\begin{array}{c}\text { Tidak } \\
\text { Tunta }\end{array}$ & 16 & 61,54 & 11 & 42,31 & 5 & 19,23 \\
s & & $\%$ & & $\%$ & & $\%$ \\
\hline Juml & $\mathbf{2 6}$ & $\mathbf{1 0 0 \%}$ & $\mathbf{2 6}$ & $\mathbf{1 0 0 \%}$ & $\mathbf{2 6}$ & $\mathbf{1 0 0 \%}$ \\
ah & & & & & & \\
\hline
\end{tabular}

(Sumber: Peneliti, 2020: 121)

Tabel 4.6

Perbandingan Rata-rata Hasil Belajar Peserta Didik Kelas XII IPS 1 SMA Negeri 1 Bandongan

\begin{tabular}{|c|c|c|}
\hline Tahap & KKM & $\begin{array}{c}\text { Nilai } \\
\text { Rata- } \\
\text { rata }\end{array}$ \\
\hline Pra Siklus & 67 & 60,38 \\
\hline Siklus I & 67 & 68,27 \\
\hline Siklus II & 67 & 79,81 \\
\hline
\end{tabular}


(Sumber: Peneliti, 2020: 119)

Gambar 4.3

Diagram Perbandingan Hasil Belajar Pra Siklus, Siklus I dan Siklus II

\section{PERBANDINGAN HASIL BELAJAR PRA SIKLUS, SIKLUS I DAN SIKLUS II}

E Tuntas $\mathrm{E}$ Tidak Tuntas $\mathrm{E}$ Rata-rata Kelas

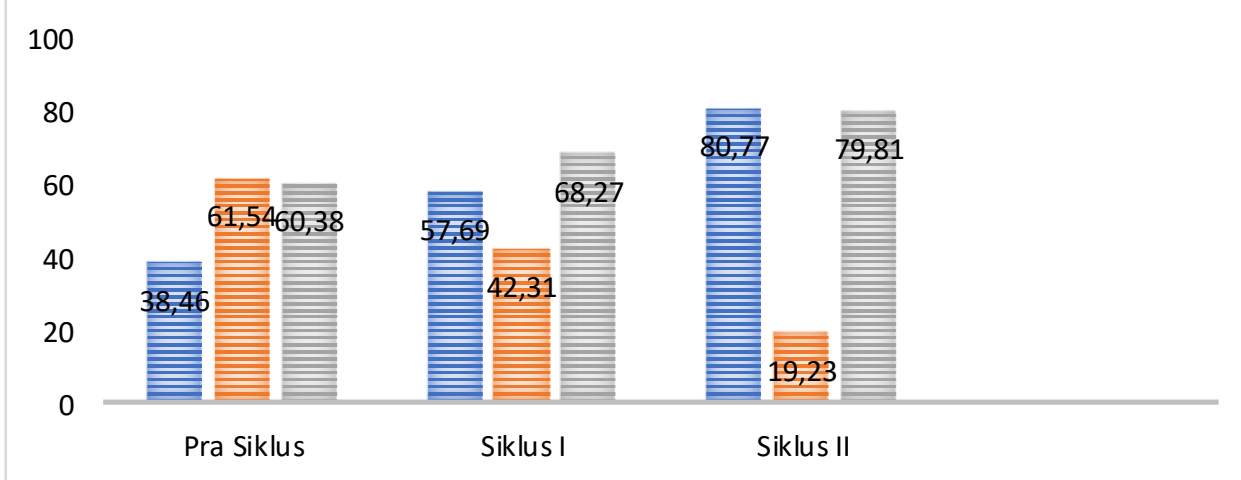

(Sumber: Peneliti, 2020: 121)

Berdasarkan data pada gambar 4.3, maka dapat dilihat ketercapaian dari setiap indikator hasil belajar peserta didik pada siklus II sudah menunjukkan peningkatan dari hasil sebelumnya. Peningkatan dari siklus I ke siklus II untuk ketuntasan belajar sebesar 23,08\% dan untuk rata-rata kelas mengalami peningkatan 11,54\%. Peningkatan peserta didik dalam hasil belajar setelah dilakukan tindakan siklus II sebanyak 6 peserta didik yang mengalami peningkatan dari hasil siklus I.

Berdasarkan peningkatan hasil belajar peserta didik dari setiap indikator telah dijelaskan di siklus II diperoleh nilai peningkatan yang berbeda. Pada siklus II peserta didik diberikan perlakuan dan tindakan yang agak berbeda dari siklus I walaupun sama-sama menggunakan model Problem Based Learning melalui aplikasi LMS "SMABA-EL" seperti kegiatan diskusi dilakukan secara berkelompok untuk meningkatkan keaktifan peserta didik dan diadakan ice breaking untuk 
mengembalikan semangat peserta didik dalam belajar.

Berdasarkan data di atas menunjukkan peningkatan dari pra siklus ke siklus I untuk ketuntasan belajar sebesar $19,23 \%$ dan untuk rata-rata kelas mengalami peningkatan $7,89 \%$. Peningkatan peserta didik dalam hasil belajar setelah dilakukan tindakan siklus I sebanyak 5 peserta didik yang mengalami peningkatan dari hasil pra siklus. Pada siklus II peserta didik mengalami peningkatan yang signifikan untuk ketuntasan belajar sebesar $23,08 \%$ dan untuk rata-rata kelas mengalami peningkatan $11,54 \%$. Peningkatan peserta didik dalam hasil belajar setelah dilakukan tindakan siklus II sebanyak 6 peserta didik yang mengalami peningkatan dari hasil siklus I. Hal ini karena pada siklus II guru memberikan tindakan secara maksimal dan peserta didik sudah terbiasa dengan metode yang diterapkan oleh guru sehingga data pada diagram ketuntasan mengalami kenaikan secara signifikan.

Terbukti dari peningkatan pra siklus, siklus I dan siklus II, maka penerapan model Problem Based Learning melalui aplikasi LMS "SMABA-EL" dapat meningkatkan hasil belajar dalam pembelajaran daring mata pelajaran sosiologi materi permasalahan sosial yang disebabkan oleh perubahan sosial. Siklus pada penelitian ini dihentikan karena telah mencapai indikator keberhasilan yang telah ditentukan yaitu siklus dihentikan apabila ketuntasan peserta didik mencapai $74 \%$ dan rata-rata kelas 74 .

\section{DISKUSI}

Dari keseluruhan tahap penelitian, mulai dari pra siklus, siklus I hingga siklus II dilaksanakan evaluasi belajar secara bertahap. Pada saat melakukan pra siklus, dilaksanakan evaluasi belajar peserta didik dengan menunjukkan sebanyak 10 peserta didik $(38,46 \%)$ yang hasil belajarnya mengalami ketuntasan dengan Kriteria Ketuntasan Minimal (KKM) 67 dan nilai rata-rata kelas sebesar 60,38. Setelah dilakukan tindakan pada siklus I, hasil belajar peserta didik menunjukkan kenaikan sebesar $57,69 \%$ peserta didik yang mengalami ketuntasan dengan nilai rata-rata kelas sebesar 68,27. Hasil ini sudah 
mencapai indikator keberhasilan yang ditentukan tetapi hasil yang diperoleh belum maksimal dan masih bisa ditingkatkan maka perlu dilaksanakan tindakan pada siklus II untuk meningkatkan hasil belajar peserta didik. Kemudian di siklus II ini diperoleh hasil sebesar $80,77 \%$ peserta didik yang mengalami ketuntasan dengan nilai rata-rata kelas sebesar 79,81. Hasil ini telah mencapai indikator keberhasilan yang telah ditentukan yaitu siklus dihentikan apabila ketuntasan peserta didik mencapai $74 \%$ dan rata-rata kelas 74 . Pembentukan kelompok secara heterogen dan keterlibatan peserta didik dalam menganalisis masalah dan mencari solusi permasalahan membantu peserta didik untuk lebih memahami materi yang sedang dibahas, sebab mereka dapat aktif membaca, mencari berbagai informasi guna memperdalam materi dan berdiskusi dengan teman sebaya. Dalam kegiatan diskusi yang dibuat secara heterogen ini, terdapat perbedaan kemampuan kognitif peserta didik pada tiap kelompok sehingga peserta didik yang lebih pintar dapat membantu peserta didik dalam kelompoknya untuk memahami materi yang sedang dipelajari.

Penelitian Tindakan Kelas dengan model pembelajaran Problem Based Learning ini sesuai dengan teori belajar konstruktivisme. Problem Based Learning mendorong peserta didik mengkonstruksi pengetahuannya sendiri melalui permasalahan nyata yang membutuhkan suatu pemecahan masalah. Dari beberapa teori konstruktivisme, yang paling sesuai dari proses pembelajaran yang telah dilaksanakan adalah teori konstruktivisme menurut Vygotski, sebab ketika peserta didik terlibat dalam kegiatan diskusi yang dilaksanakan pada tiap siklusnya, mereka akan saling bertukar pendapat dan informasi, sehingga konsep dari materi tersebut dapat ditemukan peserta didik. Konstruktivisme Vygotski memandang bahwa pengetahuan dikonstruksi secara kolaboratif antar individual dan keadaan tersebut dapat disesuaikan oleh setiap individu. Ini berarti bahwa konstruktivisme Vygotski lebih menekankan pada penerapan teknik 
saling tukar pendapat dan gagasan antar individu dalam kegiatan kelompok sehingga peserta didik dapat menemukan konsep secara mandiri, seperti halnya yang dilakukan peserta didik kelas XII IPS 1 pada kegiatan diskusi.

Dari hasil tindakan, pengamatan dan pembahasan dapat ditarik kesimpulan bahwa penerapan model pembelajaran Problem Based Learning melalui aplikasi LMS "SMABA-EL" dapat meningkatkan hasil belajar dalam pembelajaran daring mata pelajaran sosiologi materi permasalahan sosial yang disebabkan oleh perubahan sosial di Kelas XII IPS 1 SMA Negeri 1 Bandongan tahun pelajaran 2020/2021.

\section{KESIMPULAN}

Berdasarkan hasil Penelitian Tindakan Kelas (PTK) yang telah dilakukan peneliti dengan menerapkan model Problem Based Learning melalui aplikasi LMS "SMABA-EL" pada peserta didik kelas XII IPS 1 SMA Negeri 1 Bandongan, maka dapat ditarik kesimpulan bahwa penerapan model Problem Based Learning melalui aplikasi LMS "SMABA-EL" dapat meningkatkan hasil belajar dalam pembelajaran daring mata pelajaran sosiologi materi permasalahan sosial yang disebabkan oleh perubahan sosial pada peserta didik kelas XII IPS 1 SMA Negeri 1 Bandongan Tahun Pelajaran 2020/2021. Pada pra siklus diperoleh rata-rata kelas 60,38 dan peserta didik yang telah mencapai KKM ada 10 peserta didik dengan prosentase $38,46 \%$. Setelah pra siklus dilakukan siklus I yang mengalami peningkatan dari pra siklus dengan rata-rata kelas 68,27 dan peserta didik yang telah mencapai KKM ada 15 peserta didik dengan prosentase $57,69 \%$. Setelah siklus I dilakukan siklus II yang mengalami peningkatan dari siklus I dengan rata-rata kelas 79,81 dan peserta didik yang telah mencapai KKM ada 21 peserta didik dengan prosentase $80,77 \%$. Dengan ini dapat disimpulkan bahwa hasil belajar peserta didik kelas XII IPS 1 SMA Negeri 1 Bandongan pada siklus I dengan siklus II mengalami peningkatan. 


\section{DAFTAR PUSTAKA}

Abdullah, A.G dan Ridwan, T. (2008). Implementasi PBL dalam Proses Pembelajaran di BPTP Bandung. Jurnal Penelitian Pendidikan. 5, (13), 1-10.

Amir, Taufik. (2015). Inovasi Pendidikan Melalui Problem Based Learning: Bagaimana Pendidik Memberdayakan Pemelajar di Era Pengetahuan. Jakarta: Kencana.

Anwar, K. \& Harmi, H. (2011). Perencanaan Sistem Pembelajaran Kurikulum Tingkat Satuan Pendidikan (KTSP). Bandung: Alfabeta.

Arikunto, Suharsimi., Suhardjono, \& Supardi. (2011). Penelitian Tindakan Kelas. Jakarta: PT Bumi Aksara.

Azwar, S. (2012). Reliabilitas dan Validitas.Yogyakarta: Pustaka Pelajar.

Bambang, Warsita. (2008). Teknologi Pembelajaran. Jakarta: Rineka Cipta.

Basrowi. (2008). Prosedur Penelitian Tindakan Kelas. Jakarta: Ghalia Indonesia.

Buchori dan Trianto. (2007). Model Pembelajaran Terpadu dalam Teori dan Praktek. Jakarta: Prestasi Pustaka.

Hamalik, O. (2002). Perencanaan Pengajaran Berdasarkan Pendekatan Sistem. Jakarta: Bumi Aksara.

Haryono, B., Rochani, S., \& Maharromiyati. (2009). Sosiologi. Surakarta: Panitia Sertifikasi Guru Rayon 13 FKIP UNS.

Kementerian Pendidikan dan Kebudayaan. (2020). Surat Edaran Kemdikbud No 4 Tahun 2020 mengenai Pelaksanaan Pendidikan Dalam Masa Darurat Coronavirus Disease (Covid-19). Jakarta: Kementerian Pendidikan dan Kebudayaan.

M. Romli, Asep Syamsul. (2012). Jurnalistik Online: Panduan Praktis Mengelola Media Online. Bandung: Nuansa Cendekia.

Nyoman K, Ratna. (2010). Metodologi Penelitian: Kajian Budaya dan Ilmu Sosial Humaniora Pada Umumnya. Yogyakarta: Pustaka Pelajar.

Purwanto, M. N. (2004). Psikologi Pendidikan. Bandung: Remaja Rosdakarya.

Purwanto, Ngalim. (2009). Evaluasi Hasil Belajar. Yogyakarta: Pustaka Pelajar. 
Rosyidi, A. \& Marjono. (2008). Meningkatkan Kualitas Hasil Belajar IPA Melalui Alternatif Model Pembelajaran. Paedagogia: Jurnal Penelitian Pendidikan, 11 (2) $91-176$.

Rusman. (2012). Model-Model Pembelajaran Mengembangkan Profesionalisme Guru. Jakarta: Raja Grafindo Persada.

Sagala, S. (2010). Konsep dan Makna Pembelajaran. Bandung: Alfabeta.

Santana, Septiawan. (2005). Jurnalisme Kontemporer. Jakarta: Yayasan Obor Indonesia.

Sudjana, Nana. (2017). Penilaian Hasil Proses Belajar Mengajar. Bandung: Remaja Rosdakarya.

Sunarto, K. (2000). Pengantar Sosiologi Edisi Revisi. Jakarta: Fakultas Ekonomi Universitas Indonesia.

Suprijono, A. (2009). Cooperative Learning Teori dan Aplikasi PAIKEM. Yogyakarta: Pustaka Belajar.

Suyadi. (2010). Panduan Penelitian Tindakan Kelas. Yogyakarta: Diva Press.

Tim Redaksi. (2007). Kamus Besar Bahasa Indonesia Edisi Ketiga. Jakarta: Balai Pustaka. 